\title{
Effect of fresh chopped leaves of certain plants as biofumigants for management Meloidogyne spp. on tomato plants
}

\author{
Mousa E.M. ${ }^{1}$; Mahdy, M.E. ${ }^{1 *}$; Sorial, Mervat, E. ${ }^{1}$ and Younis, Dalia M. ${ }^{2}$ \\ 1 Dept. of Agric. Botany, Fac. of Agric., Menoufiya Univ., Shebin El-Kom, Egypt. \\ ${ }^{2}$ Dept. of Nematology, Plant Pathology Research Institute, Agric. Res. Center, Giza, Egypt.
}

\section{ABSTRACT}

In this research four plants i.e. Moringa (Moringa oleifera), Cabbage (Brassica aleracea), Cassia (Cassia nodosa) and Chinaberry (Melia azedaroch) were mixed, at three levels 1, 2 and $4 \%$ of soil weight to manag root-knot nematodes, Meloidogyne spp. under greenhouse conditions. Results revealed that chapped leaves of the four evaluated plants significantly, reduced all related nematode parameters i.e. number of galls, egg masses, females and developmental stages / root system, eggs / egg mass and number of juveniles / $250 \mathrm{~g}$ soil, in comparing with nematode alone. The highest significant reduction in galls, egg masses and J2 / $250 \mathrm{~g}$ soil (93, 92.8 and $89.6 \%$, respectively) obtained with moringa at $4 \%$ of soil weight, followed by cabbage chapped leaves at $4 \%(90.8,88.9$ and $85.8 \%$, respectively), whereas the lowest one observed with cassia chapped leaves at $1 \%$. Generally, the effective dose was $4 \%$ regardless the plant species and the effective plant was moringa regardless the rate significantly enhanced all vegetative plant growth parameters i.e. fresh shoot and root weight (g), dry shoot weight (g), plant height and root length (g). Results showed also all treatments significant increase antioxidant enzymes activity i.e. peroxidase and phenoloxidase, total sugars, total phenols and proline concentration. Membrane leakage showed also highly significant decrease with all treatment compared with the plant treated with nematode alone.

Key Words: Moringa, Root-knot nematode, Meloidogyne spp., biofumigants, fresh chopped leaves.

\section{INTRODUCTION}

Root-knot nematodes Meloidogyne spp. are obligate endo-parasites and very damaging plant pests which are considered to be limited factor in crop production and agricultural productivity (Bakr et al., 2011 and Ibrahim, 2011). Most cultivated plant species are susceptible to root-knot nematode infection (Sasser and Carter, 1985). They attack more than 2000 species of plants and almost all cultivated plants such as vegetables, ornamentals in Egypt. Root-knot nematodes, Meloidogyne spp. are becoming serious pests to most vegetable crops, especially tomato plants and cause severe yield losses in new reclaimed soil. Infected plants suffer from vascular damages which disturb water and mineral uptake (Abd-Elgawad and Aboul-Eid, 2001 and Luc et al., 2005). Chemical nematicides are considered the most effective method in suppressing and controlling root-knot nematodes, but its means environmental pollution and very expensive in price (Adegbite and Adesiyan, 2001; Abd-Elgawad, 2008). During the last decades, nematologists worldwide searched for cheaper, safer and eco-friendly alternatives methods i.e. biological and cultural methods to control the plant parasitic nematodes. Recently, these harmful nematodes have been controlled using a broodspectrum, of safety method i.e. beneficial soil organisms soil fumigants which exhibited vertebrate toxicity (Shreiner et al., 2001 and Cox, 2006). Control of nematodes has become 
increasingly different due to the removal of many nematicides and soil fumigants from the market because of their toxicity and adverse effects on the environment (Davies and Spiegil, 2011). Biofumigation is an alternative management strategy for controlling soil bonne diseases especially rootknot nematodes, Meloidogyne spp. Biofumigation was defined by several researchers that occurs when volatile compounds with pesticidal properties are released during decomposition of plant materials of which cruciferous plants belonging to Brassica spp. mustard (Griffiths et al., 2011 and Salem and Mahdy, 2015), Broccoli (Roubtsova et al. 2007) and cabbage (Youssef and Lashin, 2013) that contains glucosinolate compounds as a toxic products (Brown and Morra, 1996 and Kirkegaard and Sarwar, 1998).

\section{MATERIALS AND METHODS}

In this experiment four plants i.e. moringa, cabbage, Cassia and chinaberry were mixed in nematode natural infested soil two weeks before tomato seedlings transplanting into pots (15 cm in diameter) as chopped fresh leaves. Each pot contain $2 \mathrm{~kg}$ soil contains 24000 freshly second stage juvenile of Meloidogyne spp. (12000 $\mathrm{J} 2 \mathrm{~S} / \mathrm{kg}$ ) Plants were mixed at three levels 1,2 and $4 \%$ of soil weight. Pots watered and covered with transparent plastic sheets for two weeks. Pots were kept moist under greenhouse conditions to allow the amendments to decomposition. Numbers of live and dead juveniles were determined in 100 $\mathrm{g}$ soil, after soil covering for two weeks with transparent plastic sheets. Three weeks-old tomato seedlings cv. Beto86 were transplanted into pots (one seedling / pot) after removing the plastic sheet. Six replicates were used for each particular treatment. Plants watered daily and fertilized once a week with nutrient solution obtained from the International Egypt Company for Agricultural and Industrial Developing, with $5 \mathrm{ml}$ of $2 \mathrm{~g} / \mathrm{L}(\mathrm{N}: \mathrm{P}: \mathrm{K}$, 20: 20: 20).

Fifteen days after tomato seedlings transplanting, plants were uprooted, and their roots carefully washed under running tap water larvae penetration rate determined after staining the roots with sodium hyochlorite-acid fuchsin stain. Roots transfers into a boiling acid fuchsin for 30 seconds as described by Byrd et al. (1983). Excess stain was removed by rinsing the stained roots in running tap water. Roots then placed in $20-30 \mathrm{ml}$ glycerin acidified with a few drops of $5 \mathrm{~N} \mathrm{HCl}$, heated to boiling and then cooled and examined. Numbers of penetrated juveniles were counted under a stereomicroscope by pressing the root segments between microscopic glass slides.

Two months after tomato seedlings transplanting, plants were uprooted, and their roots were carefully washed under running tap water. Numbers of galls, egg masses, females, developmental stages / root system, eggs/egg mass, number of juveniles / $250 \mathrm{~g}$ soil, final nematode population (PF) as well as reproduction factor (RF) were determined.

Final nematode population (PF) was assessed according to the equation:

$\mathrm{PF}=$ (no of egg masses $\times$ No. of eggs / egg mass) + No. of females + No. of developmental stages + No. of juveniles in soil

\section{RF=PF/PI (Sasser et al. 1984)}

Egg masses were stained prior to counting by dipping the infected roots in Phloxin-B solution $(0.15 \mathrm{~g} / \mathrm{L}$ tap water) for 20 minutes as described by Daykin and Hussey (1985). Females and developmental stages/root system 
were evaluated by submerging the roots in a beaker full of tap water at room temperature until they became softened. The roots were then washed through 250 and $500 \mu \mathrm{m}$ sieves to separate the females and developmental stages from the root debris, counted under a stereomicroscope (Mahdy, 2002). Soil nematode population was enurmerated by extraction root-knot nematode juveniles (J2S) by using the tray modification of Baermann funnel as described by Barker (1985). Vegetative plant growth parameters i.e. plant height $(\mathrm{cm})$, root \& shoot length $(\mathrm{cm})$, fresh root and shoot weight $(\mathrm{g})$, dry root and shoot weight (g). Chemical components i.e. membrane leakage, antioxidant enzymes (Phenoloxidase and Peroxidase), total sugars, total phenols, and proline content, also were determined.

\section{Statistical analysis:}

The collected data were subjected to statistical analysis of using the F-test and means were compared by the LSD at 0.05 level of probability as described by Snedecor and Cochran (1967) and using Costat Software (2008) Version 6.40 .

\section{RESULTS}

Data presented in Table (1) revealed that chopped leaves of the four evaluated plants mixed thoroughly with naturally infested soil as a biofumigants at 1,2 and $4 \%$ of soil weight were significantly effective in reducing the penetration rate of second stage juveniles of Meloidogyne spp. into tomato roots after 15 days of tomato seedlings cultivation compared with plants cultivated in nematode infested soil only. The highest reduction percentage of penetrated larvae into tomato roots recorded with chopped leaves of moringa, cabbage and chinaberry at $4 \%$ as it reached 98.1 , 97.4 and $96.2 \%$, respectively.

Moringa at $4 \%$ recorded the highest percentage of dead larvae in $100 \mathrm{~g}$ soil by $89.3 \%$, followed by cabbage $(85.7 \%)$ at $4 \%$ and moringa at $2 \%$ $(70.8 \%)$, whereas cassia and chinaberry at $1 \%$ were the least effective ones by $40 \%$.

Data presented in Table (2) revealed that all chopped leaves of tested plants at all three doses significantly decreased all nematode parameters i.e. number of galls, egg masses, females, developmental stages / root system, eggs / egg mass and number of juveniles / $250 \mathrm{~g}$ soil compared with plants cultivated in naturally infested soil with nematode alone.

Concern the galls number, there are no significant differences between all chopped leaves of all evaluated plants at $4 \%$ in reducing number of galls, but there is a significant difference between them, and plants grown in soil infested with nematode alone.

Moringa gave the highest reduction in number of galls followed by cabbage and chinaberry at $4 \%$ of soil weight. Results also showed that all plants at all doses significantly reduced number of egg masses/root system compared with plants grown in nematode naturally infested soil as shown in Fig. (1). Moringa at $4 \%$ gave the highest reduction of eggs / egg mass followed by cabbage and chinaberry at $4 \%$. The greatest second stage numbers inhibition recorded with moringa at $4 \%$, followed by cabbage and chinaberry.

Figure (2) showed that all evaluated plants as a chopped leaf at doses of 1 , 2 and $4 \%$ increased the reduction percentage of galls and egg masses as well as eggs / egg mass. The reduction percentage in these parameters ranged between 17.7 and $92.9 \%$. 
Table (1). Effect of fresh chopped leaves of some plants at different doses as biofumigants on nematode larvae penetration rate into tomato roots.

\begin{tabular}{c|c|c|c|c}
\hline Treatments & $\begin{array}{c}\text { Doses } \\
\%\end{array}$ & $\begin{array}{c}\text { Mean number of } \\
\text { penetrated larvae }\end{array}$ & $\begin{array}{c}\text { \% Reduction of } \\
\text { penetrated larvae }\end{array}$ & $\begin{array}{c}\text { \% Larvae dead in } \\
100 \mathrm{~g} \text { soil }\end{array}$ \\
\hline \multirow{3}{*}{ Cabbage } & 1 & $250.0 \mathrm{~d}$ & 90.4 & 58.3 \\
& 2 & $150.0 \mathrm{f}$ & 94.2 & 50.0 \\
& 4 & $66.6 \mathrm{~h}$ & 97.4 & 85.7 \\
\hline \multirow{3}{*}{ Cassia } & 1 & $316.6 \mathrm{~b}$ & 87.8 & 40.0 \\
& 2 & $250.0 \mathrm{~d}$ & 90.4 & 46.0 \\
& 4 & $233.3 \mathrm{e}$ & 91.03 & 60.0 \\
\hline \multirow{3}{*}{ Moringa } & 1 & $150.0 \mathrm{f}$ & 94.2 & 66.7 \\
& 2 & $100.0 \mathrm{~g}$ & 96.2 & 70.8 \\
& 4 & $50.0 \mathrm{i}$ & 98.1 & 89.3 \\
\hline \multirow{2}{*}{ Chinaberry } & 1 & $300.0 \mathrm{c}$ & 88.5 & 40.0 \\
& 2 & $250.0 \mathrm{~d}$ & 90.4 & 66.0 \\
\hline \multicolumn{2}{c}{ C+ (nematode alone) } & $100.0 \mathrm{~g}$ & 96.2 & - \\
\hline
\end{tabular}

Columns followed by different letters are significantly different according to Duncan's Multiple Range Test $(p<0.05)$.

Table (2). Effect of fresh chopped leaves of some plants at different doses as bio-fumigants for management Meloidogyne spp. on tomato plants.

\begin{tabular}{|c|c|c|c|c|c|c|c|c|c|}
\hline Treatment & $\begin{array}{l}\text { Dose } \\
\text { s \% }\end{array}$ & $\begin{array}{l}\text { Galls / } \\
\text { root } \\
\text { system }\end{array}$ & $\begin{array}{c}\text { Egg } \\
\text { masse } \\
\text { s / root } \\
\text { system }\end{array}$ & $\begin{array}{c}\text { Eggs / egg } \\
\text { mass }\end{array}$ & $\begin{array}{c}\text { Develop. } \\
\text { stages / } \\
\text { root system }\end{array}$ & $\begin{array}{l}\text { Female } \\
\text { s / root } \\
\text { system }\end{array}$ & $\begin{array}{c}\mathrm{J} 2 / 250 \mathrm{~g} \\
\text { soil }\end{array}$ & PF & RF \\
\hline Cabbage & $\begin{array}{l}1 \\
2 \\
4 \\
\end{array}$ & $\begin{array}{c}82.7 \mathrm{bcd} \\
55.0 \mathrm{fgh} \\
33.7 \mathrm{ij} \\
\end{array}$ & $\begin{array}{l}45.3 b \\
32.7 b \\
19.0 b\end{array}$ & $\begin{array}{c}310.0 \mathrm{bc} \\
240.0 \mathrm{def} \\
208.3 \mathrm{fg}\end{array}$ & $\begin{array}{c}303.3 \mathrm{cde} \\
280.0 \mathrm{cdef} \\
180.0 \mathrm{fg}\end{array}$ & $\begin{array}{c}45.7 b \\
33.7 \mathrm{bcd} \\
19.0 \mathrm{ef}\end{array}$ & $\begin{array}{l}350.0 \mathrm{~cd} \\
300.0 \mathrm{~cd} \\
250.0 \mathrm{~cd}\end{array}$ & $\begin{array}{l}\text { 14742.0b } \\
8181.7 \mathrm{~b} \\
4406.7 \mathrm{~b}\end{array}$ & $\begin{array}{l}1.23 b \\
0.68 b \\
0.37 b \\
\end{array}$ \\
\hline Cassia & $\begin{array}{l}1 \\
2 \\
4\end{array}$ & $\begin{array}{c}\text { 98.3b } \\
\text { 72.7cdef } \\
\text { 59.0efgh }\end{array}$ & $\begin{array}{l}48.3 b \\
43.3 b \\
33.7 b\end{array}$ & $\begin{array}{c}370.0 \mathrm{~b} \\
301.7 \mathrm{~cd} \\
283.3 \mathrm{cde}\end{array}$ & $\begin{array}{c}440.0 \mathrm{~b} \\
373.3 \mathrm{bc} \\
326.7 \mathrm{~cd}\end{array}$ & $\begin{array}{c}48.3 b \\
43.3 b \\
33.3 \\
b c d\end{array}$ & $\begin{array}{c}600.0 \mathrm{~b} \\
483.3 \mathrm{bc} \\
333.3 \mathrm{~cd}\end{array}$ & $\begin{array}{l}18959.3 b \\
13963.5 b \\
10240.5 b\end{array}$ & $\begin{array}{l}1.60 \mathrm{~b} \\
1.60 \mathrm{~b} \\
0.85 \mathrm{~b}\end{array}$ \\
\hline Moringa & $\begin{array}{l}1 \\
2 \\
4 \\
\end{array}$ & \begin{tabular}{|c|}
$64.3 \mathrm{defg}$ \\
$52.7 \mathrm{ghi}$ \\
$26.0 \mathrm{j}$ \\
\end{tabular} & $\begin{array}{l}25.3 b \\
28.0 b \\
13.0 b \\
\end{array}$ & $\begin{array}{c}283.3 \mathrm{cde} \\
233.3 \mathrm{ef} \\
166.7 \mathrm{~g} \\
\end{array}$ & $\begin{array}{c}296.7 \mathrm{cde} \\
220.0 \mathrm{defg} \\
130.0 \mathrm{~g} \\
\end{array}$ & $\begin{array}{c}25.3 \mathrm{cde} \\
28.0 \mathrm{def} \\
13.7 f\end{array}$ & $\begin{array}{c}333.3 \mathrm{~cd} \\
283.0 \mathrm{~cd} \\
183.3 \mathrm{~d} \\
\end{array}$ & $\begin{array}{l}7822.8 b \\
7063.4 b \\
2394.1 b \\
\end{array}$ & \begin{tabular}{|c|}
$0.65 b$ \\
$0.59 b$ \\
$0.199 b$ \\
\end{tabular} \\
\hline Chinaberry & $\begin{array}{l}1 \\
2 \\
4\end{array}$ & $\begin{array}{c}84.7 \mathrm{bc} \\
75.3 \mathrm{cde} \\
71.3 \mathrm{hij} \\
\end{array}$ & $\begin{array}{l}43.6 \mathrm{~b} \\
33.7 \mathrm{~b} \\
20.0 \mathrm{~b} \\
\end{array}$ & $\begin{array}{c}316.7 \mathrm{bc} \\
275.0 \mathrm{cde} \\
233.3 \mathrm{ef}\end{array}$ & $\begin{array}{c}323.3 \mathrm{~cd} \\
280.0 \mathrm{cdef} \\
210.0 \text { efg }\end{array}$ & $\begin{array}{c}44.3 \mathrm{~b} \\
39.0 \mathrm{bc} \\
20.0 \mathrm{def}\end{array}$ & $\begin{array}{l}433.3 \mathrm{bc} \\
300.0 \mathrm{~cd} \\
263.3 \mathrm{~cd}\end{array}$ & $\begin{array}{c}14608.7 b \\
9886.5 b \\
5159.3 b\end{array}$ & $\begin{array}{l}.20 \mathrm{~b} \\
0.82 \mathrm{~b} \\
0.43 \mathrm{~b} \\
\end{array}$ \\
\hline \multicolumn{2}{|c|}{$\begin{array}{c}\mathrm{C}+\text { (nematode } \\
\text { alone) }\end{array}$} & $3 a$ & 180.0a & 44 & Ja & $3 a$ & 1766.7a & 83591.0 & $7.0 a$ \\
\hline
\end{tabular}

Columns followed by different letters are significantly different according to Duncan's Multiple Range Test $(p<0.05)$. 


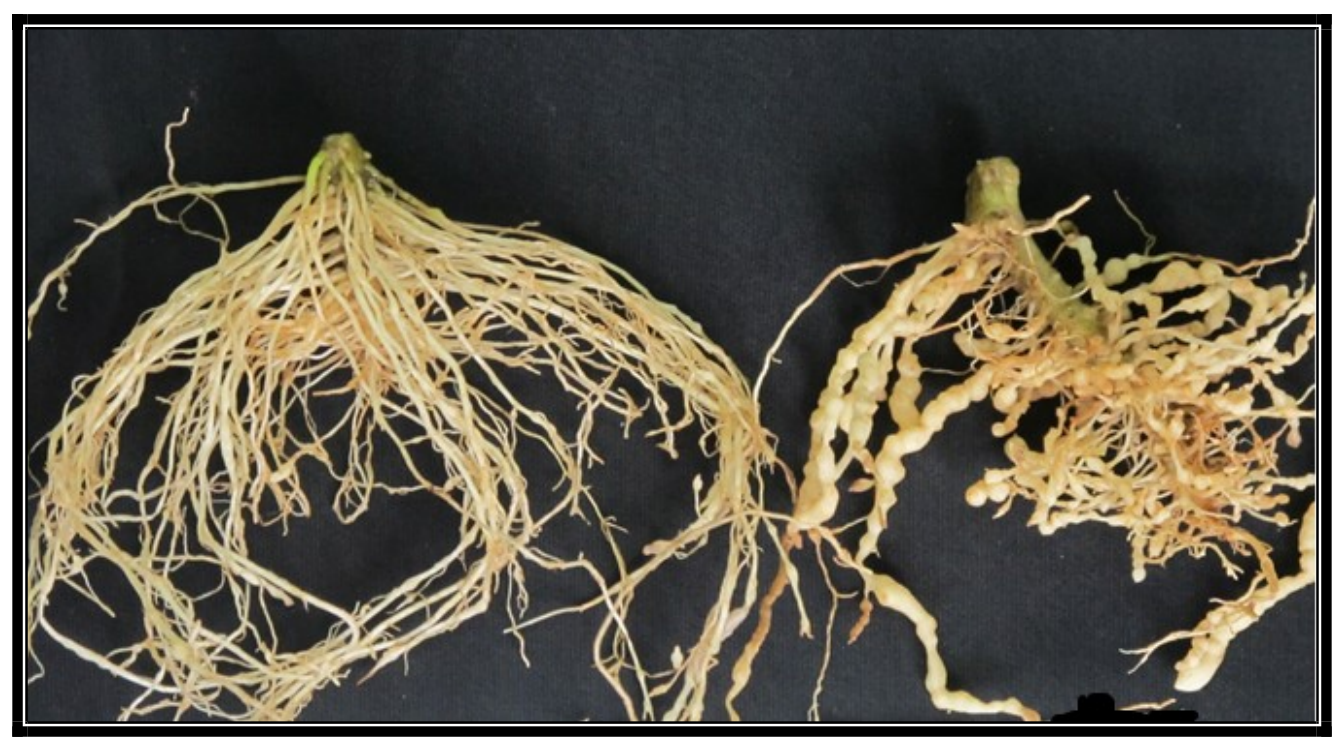

Moringa $4 \%+$ Nematode

Nematode alone

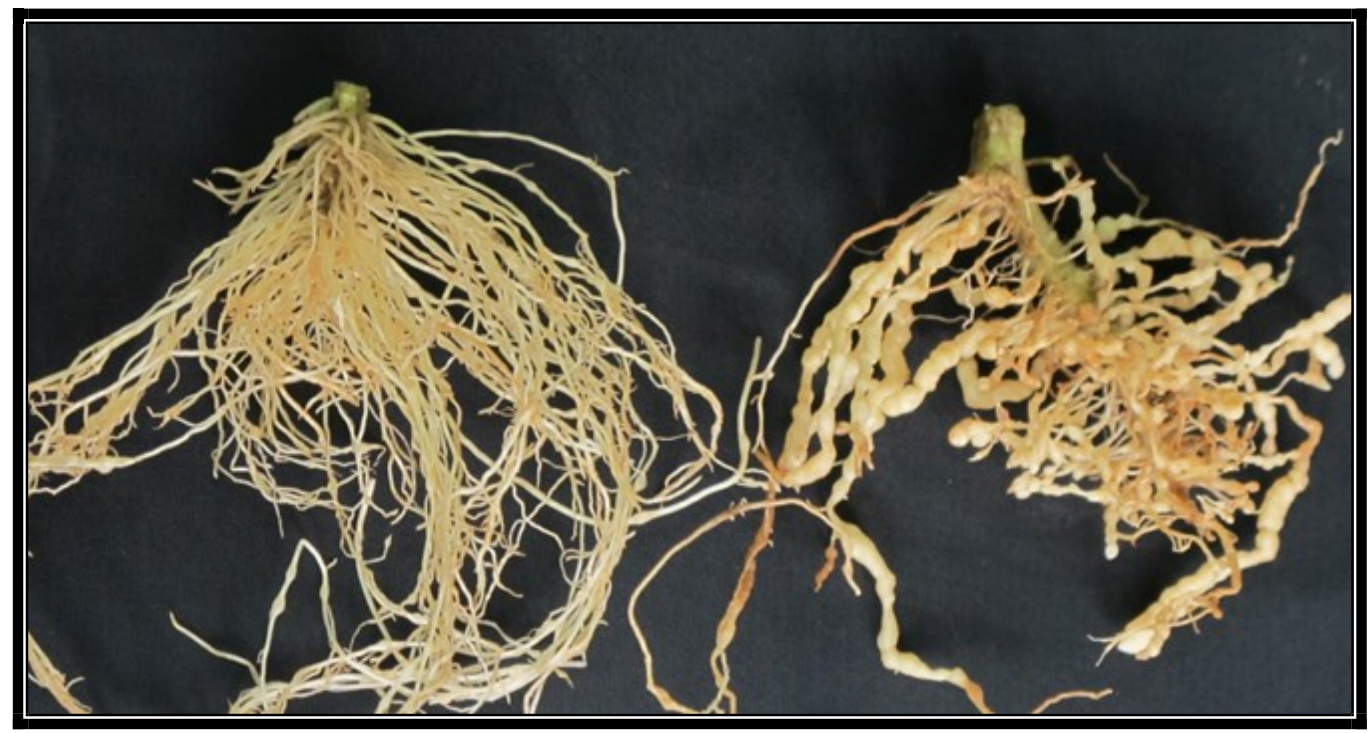

Cabbage $4 \%+$ Nematode

Nematode alone

Fig. (1). Effect of fresh chopped leaves of different plants as a biofumigants for management Meloidogyne spp.

The greatest reduction percentage of galls recorded with moringa at $4 \%$ by $92.9 \%$, followed by cabbage and chinaberry at $4 \%$ by 90.8 and $88.8 \%$, respectively. The same trend of results obtained with egg masses and eggs / egg mass as the highest reduction percentage of both parameters by 92.8 and $62.9 \%$, respectively recorded with moringa at $4 \%$.

Figure (3) revealed that moringa at $4 \%$ appeared effectiveness on the \% reduction of $\mathrm{J} 2 \mathrm{~S}$ in soil pots by $89.6 \%$ and by $97.1 \%$ for both final population and reproduction factor, followed by cabbage and chinaberry at $4 \%$. 
Data presented in Table (3) showed that mixing the different treatments with soil pots significantly enhanced all vegetative plant growth characters i.e. fresh shoot and root weights (g), dry shoot weight (g), shoot and root lengths $(\mathrm{cm})$ and plant height compared to untreated control plants. The greatest effect was recorded with the high application dose $4 \%$, followed by $2 \%$, whereas the lowest effect was recorded with $1 \%$.

Results also showed that the highest growth enhancement noticed with applying moringa at $4 \%$, followed by cabbage and chinaberry at $4 \%$, the lowest one was cassia at $1 \%$.

Data presented in Table (4) revealed that the effect of adding chopped leaves of four plants i.e. (cabbage, cassia, moringa and chinaberry) mixed thoroughly with naturally infested soil, as a biofumigants at 1,2 and $4 \%$ of soil weight on chemical components of tomato leaves with root knot nematodes Meloidogyne spp.

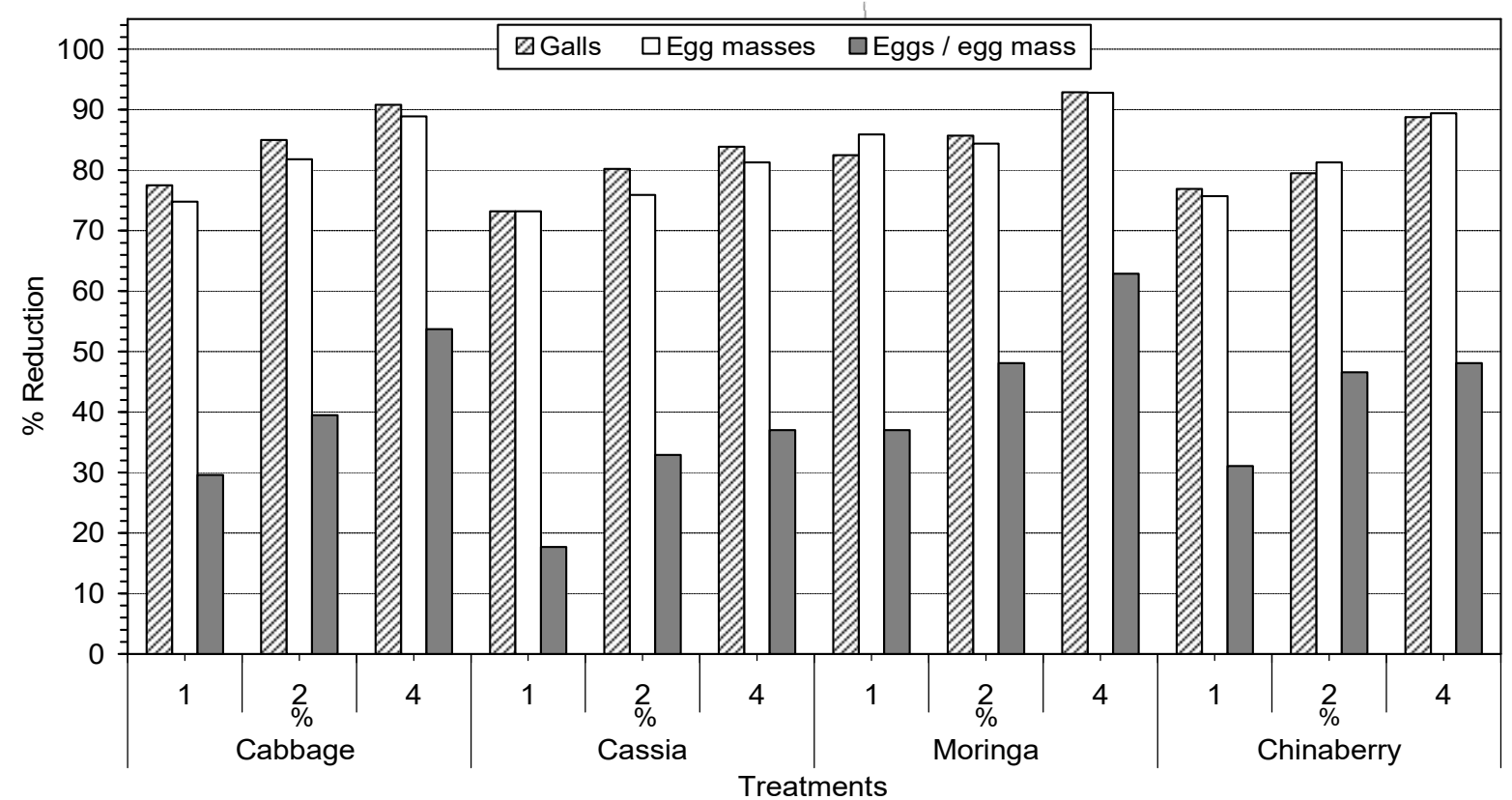

Fig. (2). Effect of fresh chopped leaves of some plants at different doses as a biofumigants on the number of galls, egg masses and eggs/egg mass of tomato plants.

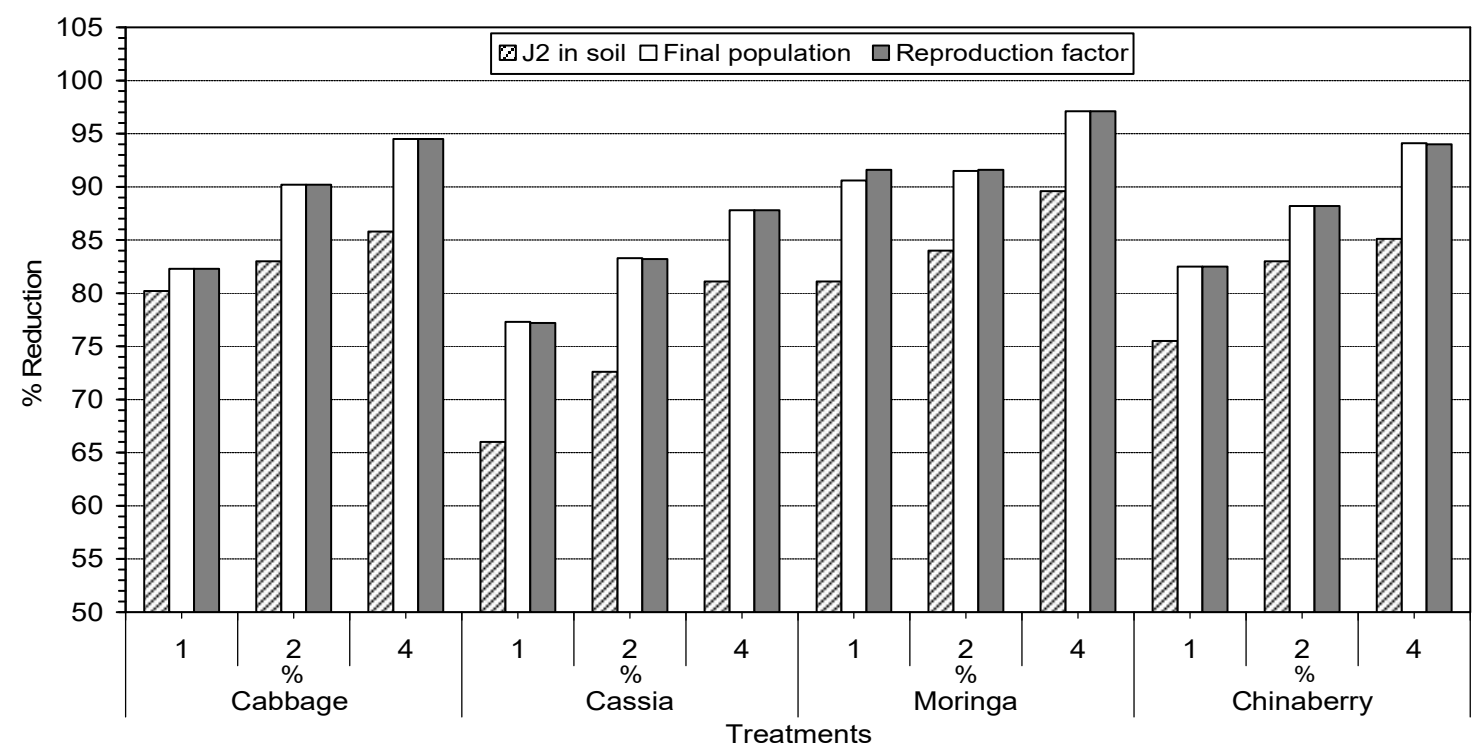

Fig. (3). Effect of fresh chopped leaves of some plants at different doses as a biofumigants on the number of $\mathrm{J}_{2} / 250 \mathrm{~g}$ soil, final population and reproduction factor. 
Table (3). Effect of fresh chopped leaves of some plants as bio-fumigants on growth characters of tomato plants infected with Meloidogyne spp.

\begin{tabular}{|c|c|c|c|c|c|c|c|}
\hline Treatment & $\begin{array}{c}\text { Doses } \\
\%\end{array}$ & $\begin{array}{l}\text { Fresh root } \\
\text { weight }(\mathrm{g})\end{array}$ & $\begin{array}{c}\text { Root length } \\
(\mathrm{cm})\end{array}$ & $\begin{array}{c}\text { Fresh shoot } \\
\text { weight }(\mathrm{g})\end{array}$ & $\begin{array}{c}\text { Shoot } \\
\text { length }(\mathrm{cm})\end{array}$ & $\begin{array}{c}\text { Plant height } \\
(\mathrm{cm})\end{array}$ & $\begin{array}{l}\text { Dry shoot } \\
\text { weight }(\mathrm{g})\end{array}$ \\
\hline Cabbage & $\begin{array}{l}1 \\
2 \\
4\end{array}$ & $\begin{array}{c}3.13 \mathrm{bcde} \\
3.8 \mathrm{abc} \\
4.2 \mathrm{a}\end{array}$ & $\begin{array}{c}11.7 \mathrm{cde} \\
15.7 \mathrm{abcd} \\
17.7 \mathrm{ab}\end{array}$ & $\begin{array}{c}19.0 \mathrm{cdef} \\
20.5 \mathrm{~cd} \\
24.8 \mathrm{ab}\end{array}$ & $\begin{array}{c}46.7 \mathrm{bcd} \\
52.3 \mathrm{abc} \\
57.0 \mathrm{ab}\end{array}$ & $\begin{array}{c}58.33 \mathrm{efg} \\
69.7 \mathrm{bc} \\
73.7 \mathrm{ab} \\
\end{array}$ & $\begin{array}{c}7.5 \mathrm{cde} \\
8.23 \mathrm{bc} \\
9.2 \mathrm{ab}\end{array}$ \\
\hline Cassia & $\begin{array}{l}1 \\
2 \\
4\end{array}$ & $\begin{array}{l}2.7 \mathrm{de} \\
3.0 \mathrm{cde} \\
3.3 \mathrm{bcd}\end{array}$ & $\begin{array}{c}\text { 11.33de } \\
\text { 13.7bcde } \\
15.7 \text { abcd }\end{array}$ & $\begin{array}{c}\text { 16.2efg } \\
\text { 17.5defg } \\
20.0 \text { cde } \\
\end{array}$ & $\begin{array}{l}38.0 \mathrm{~cd} \\
40.3 \mathrm{~cd} \\
57.0 \mathrm{ab}\end{array}$ & $\begin{array}{l}\text { 49.33h } \\
55.0 \mathrm{gh} \\
64.7 \mathrm{cde}\end{array}$ & $\begin{array}{l}6.33 \mathrm{def} \\
6.83 \mathrm{def} \\
8.0 \mathrm{bcd}\end{array}$ \\
\hline Moringa & $\begin{array}{l}1 \\
2 \\
4\end{array}$ & $\begin{array}{c}3.3 \mathrm{bcd} \\
3.8 \mathrm{abc} \\
4.3 \mathrm{a}\end{array}$ & $\begin{array}{c}12.3 \mathrm{cde} \\
16.0 \mathrm{abc} \\
19.7 \mathrm{a}\end{array}$ & $\begin{array}{c}19.8 \mathrm{cde} \\
21.3 \mathrm{bcd} \\
27.3 \mathrm{a}\end{array}$ & $\begin{array}{c}36.3 a b \\
56.3 a b \\
61.7 a\end{array}$ & $\begin{array}{c}68.7 \mathrm{bcd} \\
73.0 \mathrm{abc} \\
81.33 \mathrm{a}\end{array}$ & $\begin{array}{c}8.13 b c \\
8.6 b c \\
10.4 a\end{array}$ \\
\hline $\begin{array}{c}\text { Chinaberr } \\
y\end{array}$ & $\begin{array}{l}1 \\
2 \\
4\end{array}$ & $\begin{array}{c}3.1 \mathrm{cde} \\
3.33 \mathrm{bcd} \\
4.0 \mathrm{ab}\end{array}$ & $\begin{array}{c}10.7 \mathrm{e} \\
15.7 \mathrm{abcd} \\
17.7 \mathrm{ab}\end{array}$ & $\begin{array}{c}11.96 \mathrm{~h} \\
15.6 \mathrm{fgh} \\
22.9 \mathrm{bc}\end{array}$ & $\begin{array}{c}45.0 \mathrm{bcd} \\
49.0 \mathrm{abcd} \\
52.0 \mathrm{abc}\end{array}$ & $\begin{array}{c}55.7 \mathrm{fgh} \\
60.0 \mathrm{defg} \\
73.7 \mathrm{ab}\end{array}$ & $\begin{array}{c}7.33 \mathrm{cdef} \\
7.6 \mathrm{cde} \\
8.3 \mathrm{bc}\end{array}$ \\
\hline \multicolumn{2}{|c|}{$\mathrm{C}+$ (nematode alone) } & $2.3 e$ & $11.33 \mathrm{de}$ & $14.6 \mathrm{gh}$ & $36.7 \mathrm{de}$ & $48.0 \mathrm{~h}$ & $6.16 f$ \\
\hline \multicolumn{2}{|c|}{$\mathrm{C}-($ control $)$} & $3.8 a b c$ & $10.3 e$ & 19.0cdef & 50.0abcd & $64.3 \mathrm{cdef}$ & $7.7 \mathrm{~cd}$ \\
\hline
\end{tabular}

Columns followed by different letters are significantly different according to Duncan's Multiple Range Test $(p<0.05)$.

Table (4). Effect of fresh chopped leaves of some plants as bio-fumigants on chemical components of tomato plants infected with Meloidogyne spp.

\begin{tabular}{|c|c|c|c|c|c|c|c|}
\hline Treatment & $\begin{array}{c}\text { Conc. } \\
\%\end{array}$ & $\begin{array}{c}\text { Membrane } \\
\text { leakage } \\
(\%)\end{array}$ & $\begin{array}{c}\text { Peroxida } \\
\text { se (O.D. } \\
\text { after } 45 \\
\text { min) }\end{array}$ & $\begin{array}{c}\text { Phenoxida } \\
\text { se (O.D. } \\
\text { after } \\
2 \text { min) }\end{array}$ & $\begin{array}{l}\text { Total } \\
\text { sugar } \\
\text { (mg/g } \\
\text { dr. wt) }\end{array}$ & $\begin{array}{c}\text { Total } \\
\text { phenol } \\
\mathrm{s} \\
(\mathrm{mg} / \mathrm{g} \\
\mathrm{dr} . \mathrm{wt})\end{array}$ & $\begin{array}{c}\text { Proline } \\
\text { g/g dr. } \\
\text { wt) }\end{array}$ \\
\hline Cabbage & $\begin{array}{l}1 \\
2 \\
4\end{array}$ & $\begin{array}{l}81.01 \mathrm{e} \\
67.2 \mathrm{~h} \\
52.0 \mathrm{k}\end{array}$ & $\begin{array}{l}0.40 \mathrm{fg} \\
0.65 \mathrm{de} \\
0.99 \mathrm{~b}\end{array}$ & $\begin{array}{l}0.32 \mathrm{~g} \\
0.37 \mathrm{e} \\
0.59 \mathrm{~b}\end{array}$ & $\begin{array}{l}28.08 \\
d \\
31.2 c \\
37.4 b\end{array}$ & $\begin{array}{l}1.5 \mathrm{~h} \\
3.1 \mathrm{c} \\
4.0 \mathrm{~b}\end{array}$ & $\begin{array}{l}208.9 e \\
291.8 d \\
540.3 b\end{array}$ \\
\hline Cassia & $\begin{array}{l}1 \\
2 \\
4\end{array}$ & $\begin{array}{l}95.4 b \\
93.9 c \\
67.24 h\end{array}$ & $\begin{array}{l}0.29 \mathrm{~h} \\
0.38 \mathrm{fg} \\
0.63 \mathrm{de}\end{array}$ & $\begin{array}{l}0.17 \mathrm{k} \\
0.29 \mathrm{~h} \\
0.38 \mathrm{de}\end{array}$ & $\begin{array}{l}20.3 f \\
24.96 \\
e \\
28.08 \\
d\end{array}$ & $\begin{array}{l}1.3 \mathrm{j} \\
1.5 \mathrm{~h} \\
1.9 \mathrm{f}\end{array}$ & $\begin{array}{l}108.1 \mathrm{~g} \\
140.5 \mathrm{f} \\
291.8 \mathrm{~d}\end{array}$ \\
\hline Moringa & $\begin{array}{l}1 \\
2 \\
4\end{array}$ & $\begin{array}{l}76.1 \mathrm{~g} \\
64.8 \mathrm{i} \\
45.6 \mathrm{I}\end{array}$ & $\begin{array}{l}0.44 f \\
0.69 d \\
1.2 a\end{array}$ & $\begin{array}{l}0.33 \mathrm{~g} \\
0.39 \mathrm{~d} \\
0.65 \mathrm{a}\end{array}$ & $\begin{array}{l}31.2 \mathrm{c} \\
35.88 \\
\mathrm{~b} \\
46.8 \mathrm{a} \\
\end{array}$ & $\begin{array}{l}2.8 d \\
4.0 b \\
4.3 a\end{array}$ & $\begin{array}{l}212.5 \mathrm{e} \\
342.2 \mathrm{c} \\
684.4 \mathrm{a}\end{array}$ \\
\hline Chinaberry & $\begin{array}{l}1 \\
2 \\
4\end{array}$ & $\begin{array}{l}91.7 \mathrm{~d} \\
67.2 \mathrm{~h} \\
60.0 \mathrm{j}\end{array}$ & $\begin{array}{l}0.3 \mathrm{~h} \\
0.6 \mathrm{e} \\
0.896 \mathrm{c}\end{array}$ & $\begin{array}{l}0.21 \mathrm{j} \\
0.35 \mathrm{f} \\
0.48 \mathrm{c}\end{array}$ & $\begin{array}{l}20.3 f \\
28.08 \\
d \\
31.2 c \\
\end{array}$ & $\begin{array}{l}1.4 \mathrm{i} \\
1.6 \mathrm{~g} \\
2.03 \mathrm{e}\end{array}$ & $\begin{array}{l}212.5 e \\
219.7 e \\
345.8 c\end{array}$ \\
\hline \multicolumn{2}{|c|}{$\mathrm{C}+$ (nematode alone) } & $97.7 a$ & $0.18 \mathrm{i}$ & 0.111 & $\begin{array}{l}14.98 \\
\mathrm{~g}\end{array}$ & $0.8 \mathrm{k}$ & $104.5 \mathrm{~g}$ \\
\hline \multicolumn{2}{|l|}{ C- (control) } & $75.8 \mathrm{~g}$ & $0.35 \mathrm{gh}$ & $0.25 i$ & $11.2 \mathrm{~g}$ & $1.3 \mathrm{j}$ & $140.5 f$ \\
\hline
\end{tabular}

Columns followed by different letters are significantly different according to Duncan's Multiple Range Test $(p<0.05)$. 
Results showed that all treatments decrease membrane leakage compared to plants treated with nematode alone. The highest treatment was moringa chopped leaves at $4 \%$ in decreasing membrane leakage, followed by cabbage and chinaberry chopped leaves at $4 \%$ whereas the lowest one observed with cassia chopped leaves at $1 \%$.

The activity of antioxidant enzymes was recorded in Table (4). All fresh chopped leaves of four evaluated plants recorded a highly significant increase in the activity of peroxidase and phenoloxidase enzymes. Moringa chopped leaves at $4 \%$ recorded the highest increase in peroxidase activity by 566.7 and $242.0 \%$ when compared with plants treated nematode alone and healthy plants without nematode, respectively. The highest value of phenoloxidase enzyme recorded by moringa at $4 \%$ followed by cabbage and chinaberry at $4 \%$.

Concerning the total sugars and total phenols, the highly significant increasing in total sugars and total phenols were significant increasing in sugars and total phenols were recorded by moringa at $4 \%$ followed by cabbage at $4 \%$ when compared to the plants treated with nematode and plants without nematode. Results showed also all treatments increase proline concentration compared with plants treated with nematode alone. The highest increase in proline observed with moringa at 4\% (554.9 and $387.1 \%$ ) when compared to the plants treated with nematode and plants without nematode, respectively.

\section{DISCUSSION}

Results in this experiment indicated that all four botanicals were effective in reducing significantly all nematode parameters and significant increasing in plant growth which reflected a healthy plant compared to the untreated control. Moreover, analysis of the nematode parameters from soil and tomato roots showed that all botanicals were effective in a significant reduction of Meloidogyne spp. population considerably compared to control plants. The maximum reduction in nematode parameters and maximum increase in growth characteristics were by moringa at $4 \%$.

The management of soil-borne pathogens and pests, including plantparasitic nematodes, by amending soil with organic material is a well-known and long-practiced strategy and was reviewed by Lazarovits et al. (2001). The initial definition of "biofumigation" as a process referring to the breakdown of Brassica tissues, was expanded by Bello et al. (2004) to describe the process of biological decomposition of plant or animal byproducts, leading to the production of volatile compounds with disease and pest suppressive properties. It is now known that besides the brassicas, plants in the Caricaceae, Moringaceae, Salvadoraceae and Tropaeolaceae families also have biofumigant properties (Gouws, 2004 and Van Dam et al., 2009).

Bello et al. (2004) tested the biofumigant effect of a range of agroindustrial byproducts and livestock manures, in different doses and combinations, on the levels of $M$. incognita control. These authors concluded that the majority of materials could effectively be used. The decomposition of biofumigant plant tissues mainly releases isothiocyanates (ITCs), in addition thiocyanates, nitriles and oxozaliolinethiones (Fahey et al., 2001). 
Glucosinolates (GCs) are sulphur containing stable and non-toxic compounds, but upon tissue disruption they come in contact with myrosinase (= thioglucosidase), an enzyme endogenously present in tissues, but stored in the cell walls or the cytoplasm, away from the glucosinolates (Poulton and Moller, 1993). The enzymatic hydrolysis of glucosinolates produces volatile isothiocyanates (ITCs), nitriles, and thiocyanates (Fenwick et al., 1983). The ITCs in particular, have general biocidal properties (Kirkegaard and Sarwar, 1998). Isothiocyanates also form the active ingredient of some synthetic nematicides (methyl isothiocyanate).

GCs are sulphur containing chemicals that are produced by plants as secondary metabolites (Agrios, 2005). GCs are relatively inactively against microbes. But when hydrolyzed, the ITCs in particular, are biocidal to nematodes (Sarwar et al., 1998).

Biofumigation is performed by incorporating the green manure into the upper part of the soil where the ITCs (isothiocyanates) are released (Matthiessen \& Kirkegaard, 2006 and Jensen et al., 2010). These Glucosinolates (GLS) metabolic products are the factor of bioactivity and their fate in soil defines their residual life and thus efficacy. It must be noted that the ITCs originating for biofumigation are slowly released into the soil thus they might provide of a longer-term biological activity compared to their directly exposed to degradation synthetic analogs (Hanschen et al., 2015). ITCs can decline due to volatility, are adsorbed to soil with high organic matter due to their lipophilicity and they decompose because of biotic and abiotic soil properties (Gimsing \&
Kirkegaard, 2006; Gimsing et al., 2007; Poulsen et al., 2008; Gimsing et al., 2009). The ITCs degradation is faster in top soil than in sub soil (Gimsing et al., 2007). Nonetheless both chemical and natural ITC can also leach into the soil (Guo et al., 2003 and Laegdsmand et al., 2007).

To study the stability of GLS2 and respective nitriles as well as ITCs breakdown products, Raphanus sativus and Brassica juncea were incorporated in regulation, the improvement of soil organic matter and the suppression of weeds, all factors contributing to a holistic IPM approach in controlling plant parasitic nematodes (Kruger et al., 2013). Natural isothiocynates are toxic to organic of soil borne pest and pathogens, including nematodes (Ntalli and Caboni, 2017).

It was generally postured that the adverse influence of organic amendments on phytoparasitic nematodes in referred to numerous factors e.g. increasing host resistance to nematode infection and enhancement of growth performance. Courtency and Mallen (2008) illustrated the changing physical soil properties like cation exchanges, water retention and soil irrigation, producing chemicals during degradation like volatile fatty acids, organic acids, phenols, nitrogenous compounds, hydrogen sulphide (Zakie et al., 2004 ;Kesba \& Al-Shalaby, 2008 and Bakr, R.A. (2017).

\section{REFERENCES}

Abd-Elgawad, M.M. (2008). The current status of phytonematode management in Egypt with special reference to applicable nematicides. Egypt. J. of Agronematol., 6: 33 46.

Abd-Elgawad, M.M. and Aboul-Eid, H.Z. (2001). Effects of oxamyl, insect nematodes and serratia marcescens 
on a polyspecific nematode community and yield of tomato. Egypt. J. of Agronematol., 5: 89 97.

Adegbite, A.A. and Adesiyan, S.O. (2001). Efficacy of carbofuran (furadan) on the performance of four nematode susceptible varieties of soybean (Glycine max L. Merril). Tropical Oil Seeds J. 6: 11 - 23.

Agrios, G.N. (2005). Plant pathology, Fifth Edition. Elsevier Academic Press, China, p. 922.

Bakr, R., M. Mahdy, and E. Mousa (2011). A survey of root-knot and citrus nematodes in some new reclaimed lands in Egypt. Pakistan Journal of Nematology, 29(2): 165170.

Bakr, R.A. (2017). Utilization of Oleander Leaves and Fish Waste on Root-Knot Nematodes Control. International Journal of Current Microbiology and Applied Sciences. 6(2): 1912-1925.

Barker, K.R. (1985). Nematode extraction and bioassays. In: Gads, K.R. Barker, C.C. Carter and J.N. Sasser, eds., An Advanced Treotise on Meloidogyne, North Carolina State University, 11: $19-38$.

Bello, A.; López-Pérez, J.A., GarciaAlvarez, A.; Sanz, R. and Lacasa, A. (2004). Biofumigation and nematode control in the Mediterranean region. In R.C. Cook \& D.J. Hunt (Eds.), Proceedings of the fourth international congress of nematology, 8 - 13 June, 2002, Tenerife, Spain. Nematology monographs and perspectives. Leiden and Boston: Brill, 2: 133 149.

Brown, P.D. and Morra, M.J. (1996). Hydrolysis products of glycosinolates in Brassica nopus tissues as inhibitors of seed germination. Plant and Soil, 181: $307-316$.
Byrd, D.W.; Kirkpatrick, T. and Barker, K.R. (1983). An improved technique for clearing and staining plant tissues for detection of nematodes. J. Nematol., 15 (1): $142-143$.

Costat Software (2008). User's Manual Version 6.40 CoHort. Tusson, Arisona, U.S.A.

Courtency, R. G. and Mellen, G.J. (2008). Soil quality and barley growth as influenced by land application of two compost types. Bioresource Technol., 99: 2913 2918.

Cox, C. (2006). Fumigant factsheet: metam sodium. J. of Pesticide Reform, 26: 12 - 16 .

Davies, K. and Spiegel, Y. (2011). Root patho-systems nematology and biological control. In Davies, K. and Spiegel, Y. (Eds). Biological control of plant parasitic nematodes: building coherence between microbial ecology and molecular mechanisms. Dordrecht, the Netherlands. Springer, pp. 291 303.

Daykin, M.E. and Hussey, R.S. (1985). Staining and histopathological techniques in nematology. In: Barker, K.R., C.C. Carter and J.N. Sasser (eds), An advanced treatise on Meloidogyne, Vol. II Methodology, pp. 39 - 48. North Carolina State University Graphics, Raleigh.

Fahey, J.W.; Zolcman, A.T. and Talalay, P. (2001). The chemical diversity and distribution of glucosinolates and isothiocyanates among plants. Phytochemistry, 56: 5-51.

Fenwick, G.R.; Heaney, R.K. and Mullin, W.J. (1983). Glucosinolates and their breakdown products in food and food plants. CRC Crit. Rev. Food Sci. Nutr., 18: 123 - 201. 
Gimising, A.L.; Strobel, B.W. and Hansen, H.C.B. (2009). Degradation and sorption of 2-propenyl and benzyl isothiocyanate in soil. Environ. Toxicol. Chem., 28: 1178 1184.

Gimsing, A.L. and Kirkegaard, J.A. (2006). Glucosinolate and isothiocyanate concentration in soil following incorporation of Brassica biofumigants. Soil Biol. Biochem., 38: 2255 - 2264.

Gimsing, A.L.; Poulsen, J.L.; Laurberg, H. and Hansen, H.C.B. (2007). Formation and degradation kinetics of the biofumigant benzyl isothiocyanate in soil. Environ. Sci. Technol., 41: 4271 - 4276.

Gouws, R. (2004). Biofumigation: what is it, and what benefits can it add to existing forming systems? An international overview: CHIPS, pp. $43-44$.

Griffiths, H.M.; Gies, D. and Zitter, T.A. (2011). Brassicas as biofumigants for controlling soil borne organisms in potato production for Upstate New York and Northern Pennsylvania Fact Sheet.

Guo, M.X.; Yates, S.R.; Zheng, W. and Papiernik, S.K. (2003). Leaching potential of persistent soil fumigant residues. Environ. Sci. Technol., 37: 5181 - 5185 .

Hanschen, F.S.; Yim, B.; Winkelmann, T.; Smallo, K. and Schreiner, M. (2015). Degradation of biofumigant isothiocyanates and allyl glucosinolate in soil and their effects on the microbial. Community Composition, 10 (7): eo132931.

Ibrahim, L.K.A. (2011). Nematode pests parasitic on Agricultural field crops. Monshoot El-Maaref, Alexandria, p. 250.

Jensen, J.; Styrishave, B.; Gimsing, A.L. and Bruun, Hansen, H.C. (2010).
The toxic effects of benzyl glucosinolate and its hydrolysis product, the biofumigant benzyl isothiocyanate, to folsomia fimetaria. Environ. Toxicol Chem., 29 (2): 359 $-364$.

Kesba, H.H. and Al-Shalaby, Mona E. (2008). Survival and reproduction of Meloidogyne incognita on tomato as affected by humic acid. Nematol., 10 (2): $243-249$.

Kirkegaard. J.A. and Sarwar, M. (1998). Biorumigalion potential of brassicas. Plant and Soil, 201: $71-89$.

Kruger, D.H.M.; Fourie, J.C. and Malan, A.P. (2013). Cover crops with biofumigation properties for the suppression of plant parasitic nematodes: a review. S. Afr. J. Enol. Vitic., 34: $287-295$.

Laegdsmand, M.; Gimsing, A.L.; Strobel, B.W.; Sorensen, J.C.; Jacobsen, O.H. and Hansen, H.C.B. (2007). Leaching of isothiocyanates through intact soil following simulated biofumigation. Plant Soil, 291: 81 92.

Lazarovits, G.; Tenuta, M. and Conn, K.L. (2001). Organic amendments as a disease control strategy for soilborne diseases of high-value agricultural wops. Australasian Plant Pathology, 30: 111 - 117.

Luc, M.; Sikora, R.A. and Bridge, J. (2005). Plant parasitic nematodes in subtropical and tropical agriculture. 2nd Eds. CAB International, Walling Ford, Oxon, UK., p. 871.

Mahdy, M.E. (2002). Biological control of plant parasitic nematodes with antagonistic bacteria on different host plants. Ph.D. Thesis, Bonn University, Germany, p. 171.

Matthiessen, J.N. and Kirkegaard, J.A. (2006). Biofumigation and enhanced biodegration: opportunity and challenge in soil borne pest and 
disease management. Crit. Rev. Plant Sci., 25: 235 - 265.

Ntalli, N. and Caboni, P. (2017). A review of isothiocyanates biofumigation activity on plant parasitic nematodes. Phytochem. Rev., 16: 827 - 834.

Poulsen, J.L.; Gimsing, A.L.; Halkier, B.A.; Bjarnholt, N. and Bruun, Hansen, H.C. (2008). Mineralization of benzyl glucosinolate and its hydrolysis product the biofumigant benzyl isothiocyanate in soil. Soil Biol Biochem., 40 (1): 135 - 141.

Poulton, J.E. and Moller, B.L. (1993). Glucosinolates. In P.J. Lea (Ed.), Methods in plant biochemistry. London: Academic Perss, 9: 209 237.

Roubtsova, T.; Lopez-Perez, J.; Edwards, S. and Ploey, A. (2007). Effect of Broccoli (Brassica oleracea) tissue, incorporated at different depths in soil column on Meloidogyne incognita. J. Nematol., 39: $111-117$.

Salem, M.F. and Mahdy, M.E. (2015). Suppression of root-knot nematode through innovative mustard biofumigation. J. Food, Agric. and Sci., 3 (2): 41 - 50.

Sarwar, M.; Kirkegaard, J.A.; Wong, P.T.W. and Desmarchelier, J.M. (1998). Biofumigation potential of brassicas. III. In vitro toxicity of isotheiocyanates to soil-borne fungal pathogens. Plant and Soil, 201: 103 $-112$

Sasser, J.N. and Carter, C.C. (1985). An advanced treaties on Meloidogyne,
Biology and control. Vol. 1. North Carolina State University Graphics, p. 422.

Schreiner, R.P. Ivors, K.L. and Pinkerton, J.N. (2001). Soil solarization reduce arbuscular mycorrinizal fungi as a consequence of weed suppression. Mycorrhiza, 11: $273-277$.

Snedecor, G. W. and W. G. Cochran (1967). Statistical methods.

Van Dam, N.M.; Tygat, T.O.G. and Kirkegaard, J.A. (2009). Root and shoot glucositolates: a comparison of their diversity, function and interactions in natural and managed ecosystems. Phytochem. Rev., 8: $171-186$.

Van Dam, N.M.; Tygat, T.O.G. and Kirkegaard, J.A. (2009). Root and shoot glucositolates: a comparison of their diversity, function and interactions in natural and managed ecosystems. Phytochem. Rev., 8: $171-186$.

Youssef, M.M.A. and Lashein, A.M.S. (2013). Effect of cabbage (Brassica oleracea) leaf residue as obiofumigant on root-knot nematode, Meloidogyne incognita infecting tomato. J. Plant Prot. Res., 53: 271 274.

Zakie, M.J.; Javed, S.; Abid, M.; Khan, $H$. and Moinuddin, M. (2004). Evaluation of some chemicals against root-knot nematode Meloidogyne incognita. Intr. J. Biol. Biotechnol., 1: 613 - 618 . 